\title{
Kinetic and Isotherm Adsorption Studies on Phenol Removal from Water by Synthesized Dinitrodiphenyldiquinoline Adsorbent
}

\author{
Solhe F. Alshahateet*, Salah A. Al-Trawneh, and Mohammed M. Al-Mahadeen
}

\begin{abstract}
The use of dinitrodiphenyldiquinoline (DNDPDQ) for the first time as an adsorbent surface for the highly irritating phenol molecules (adsorbate) from contaminated aqueous phase was investigated. The optimum adsorption conditions were achieved by running adsorption experiments at different initial concentration of the adsorbate, different contact time between the adsorbent and adsorbate, different $\mathrm{pH}$ of the aqueous phase containing the adsorbate, and different temperature. The optimum removal conditions were achieved at initial concentration of $5 \mathrm{ppm}$ of the adsorbate at ambient temperature of $25{ }^{\circ} \mathrm{C}$ and $\mathrm{pH} 5$ with agitating time of $15 \mathrm{~min}$. Kinetic study for the current adsorption process proved that the adsorption mechanism adopted the pseudo $2^{\text {nd }}$ order model made by Ho \& McKay (rate constant (k) value of $0.087 \mathrm{~g} \mathrm{mg}$ ${ }^{1} \min ^{-1}$ and $q_{\mathrm{e}} ; q_{\max }$ values of 35.71 and $22.73 \mathrm{mg} / \mathrm{g}$, respectively). Finally, our adsorption isotherm studies found that the current adsorption study is a favorable spontaneous exothermic process.
\end{abstract}

Keywords-Adsorption, Dinitrodiphenyldiquinoline, Kinetic and isotherm studies, Phenol

\section{INTRODUCTION}

Presence of large quantities of organic compounds in both water and atmosphere is considered to be a great problem to environmental scientists worldwide who use the term of organic pollutants to describe such problem. Phenols which are one of these toxic organic pollutants are considered to be priority pollutants due to their serious harmful to living organisms even with very low concentrations [1]. Different techniques where used to treat the contaminated sources of water, among these, adsorption technique was widely applied using different adsorbent surfaces such activated carbon and other natural and synthesized adsorbent materials [2-5]. Recently, our research group was developing and synthesizing a series of new lattice inclusion compounds and investigating their supramolecular behavior and applications [6-11]. The dinitrodiphenyldiquinoline (DNDPDQ) V-shape heterocyclic lattice host is one of the most interesting host molecules [12]. Its supramolecular behavior is unique compared to other

Solhe F. Alshahateet*, Faculty of science / mutah university- Jordan, Email: solhe_alshahateet@yahoo.com, Tel: +96232372380, Fax: +96232375540

Salah A. Al-Trawneh, Faculty of science / mutah university- Jordan, Email: salah_trawneh@yahoo.com; Tel.: +962795217791

Mohammed M. Al-Mahadeen, Faculty of science / mutah universityJordan, Email: malmahadeen@yahoo.com; Tel.: +962796443766 diquinoline derivatives, in which it formed selectively hostguest complexes with polar functional groups. However, no adsorption studies were conducted using such family of organic host molecules (diquinoline derivatives). DNDPDQ compound was re-synthesized, and its behavior as adsorbent surface for different organic pollutants. The target organic pollutant investigate in this study was the toxic phenol compound. Kinetic and isotherm models were applied to understand the mechanism of adsorption process.

\section{MATERIALS AND METHODS}

A. Synthetic adsorbent 2,10-dinitro-8,16-diphenyl6,7,14,15-tetrahydro-7,15-methanocycloocta[1,2-b:5,6$b^{\prime}$ diquinoline 3

Adsorbent compound $\mathbf{3}$ was resynthesized according to a recently published procedure [13] as presented in Fig. 1. A mixture of 2-Amino-5-nitrobenzophenone 1 (0.2 mol) and racemic bicycle[3.3.1]nonane-3,7-dione $2(0.1 \mathrm{~mol})$ in presence of catalytic amount of solid sodium hydroxide (ca. $5 \%$ ) was ground with a mortar and pestle at room temperature until it formed a gummy material which solidified upon standing overnight. The reaction mixture was then reground and poured into $\mathrm{HCl}(5 \mathrm{~mL}, 2 \mathrm{M})$; the solid was collected and dried to give compound 3 .
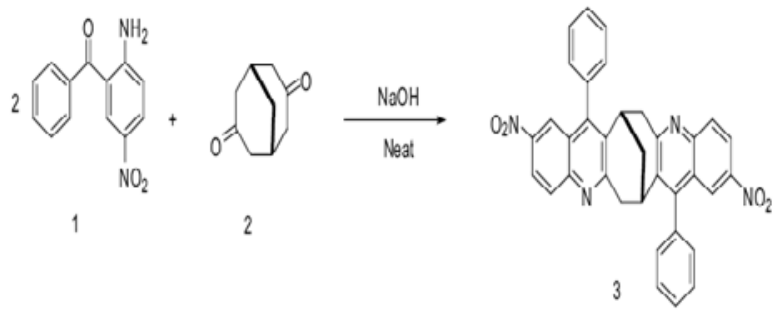

Fig. 1. Synthetic route for 2,10-dinitro-8,16-diphenyl-6,7,14,15tetrahydro-7,15-methanocycloocta[1,2-b:5,6- $\left.b^{\prime}\right]$ diquinoline 3

\section{B. Regents and glassware}

All chemicals and reagents were obtained commercially and used without further purification. Solvents used in this study were analytical reagent grade.

\section{Apparatus and instrumentation}

$\mathrm{pH}$ measurements were done using glass electrode $\mathrm{pH}$ meter model pH 525 (WTW ${ }^{\circledR}$, Weilheim, Germany). The pH meter 
was calibrated based on $\mathrm{pH} 4, \mathrm{pH} 7$ and $\mathrm{pH} 10$ buffer solutions at $25^{\circ} \mathrm{C}$ according to standard method [14]. Standard solutions using pure phenol were prepared in order to obtain a calibration curve is outlined as follows:

\section{a- Preparations of buffer solution}

34 gram of ammonium chloride is added to 200 grams of potassium sodium tertarate and $150 \mathrm{ml}$ of ammonia solution in one liter volumetric flask and diluted with distilled water to one liter. $\mathrm{pH}$ was adjusted to $\mathrm{pH} 10$ using phosphoric acid.

\section{b- Measurement of phenols}

A volume of $500 \mathrm{ml}$ of the matrix solution was adjusted to $\mathrm{pH} 4$ using phosphoric acid and sodium hydroxide. Five $\mathrm{ml}$ of potassium hexacyanofrrate solution, five $\mathrm{ml}$ aminoantipyrine solution and $20 \mathrm{ml}$ buffer was added and allowed the reaction to complete for 15 minutes. Ten $\mathrm{ml}$ of $\mathrm{CH}_{2} \mathrm{Cl}_{2}$ was added and mixed well where the color will develop after 10 minutes. $\mathrm{CH}_{2} \mathrm{Cl}_{2}$ layer was filtered through filter paper containing anhydrous sodium sulfate and the dried extract was collected in $25 \mathrm{ml}$ volumetric flask. The outcome was measured using spectrophotometer at $460 \mathrm{~nm}$. Batch adsorption experiments were conducted to determine the optimum phenol adsorption parameters and conditions

\section{Effect of $\mathrm{pH}$}

Different adsorption experiments were conducted at $\mathrm{pH}$ values 4, 5, 6, and 7. A $0.1 \mathrm{~g}$ sample of solid adsorbent 3 and $100 \mathrm{~mL}$ of $1 \mathrm{ppm}$ solution of pure phenol were mechanically agitated at room temperature for $15 \mathrm{~min}$. The adsorbent was filtered and the absorbance of the filtrate was measured to determine its concentration.

\section{E. Effect of agitation time}

The optimum agitation time between compound $\mathbf{3}$ and the phenol standard solution was obtained by conducting adsorption experiments at different agitation time in the range 0-30 min. A $0.1 \mathrm{~g}$ sample of solid adsorbent 3 and $100 \mathrm{~mL}$ of $1 \mathrm{ppm}$ solution of pure phenol were mechanically agitated at room temperature and measured optimum $\mathrm{pH}$.

\section{F. Effect of initial concentration}

The optimum initial concentration used to achieve the maximum removal efficiency in this study was obtained by running adsorption experiments at phenol standard initial concentration of 1,3 , and $5 \mathrm{ppm}$ at room temperature and measured optimum $\mathrm{pH}$.

\section{G. Effect of temperature}

The optimum temperature used to obtain maximum removal efficiency as well as the isotherm study was investigated by performing adsorption experiments at $25,35,40$, and $45{ }^{\circ} \mathrm{C}$ and at the measured optimum agitation time, initial concentration, and $\mathrm{pH}$.

\section{H. Data analysis}

The efficiency of using adsorbent $\mathbf{3}$ to remove phenol from aqueous samples was calculated from the mass balance, which is the amount of phenol adsorbed by compound $\mathbf{3}$. The amount of phenol which was removed from the standard solution is given by equation (1) (14):

$$
\mathrm{q}_{\mathrm{e}}=\left(\mathrm{C}_{\mathrm{i}}-\mathrm{C}_{\mathrm{e}}\right) / \mathrm{S}
$$

where $\mathrm{q}_{\mathrm{e}}$ is the phenol concentration adsorbed at equilibrium ( $\mathrm{mg}$ of phenol per $\mathrm{g}$ of compound 3 ), $\mathrm{C}_{\mathrm{i}}$ is the initial concentration of phenol solution (ppm), $C_{e}$ is the equilibrium concentration of the phenol solution (ppm), $\mathrm{S}$ is the dosage (slurry) concentration and can be expressed by equation (2):

$$
\mathrm{S}=\mathrm{m} / \mathrm{V}
$$

where $(\mathrm{V})$ is the initial volume of the phenol solution used and $\mathrm{m}$ is the mass of adsorbent. The percentage of the adsorption can be calculated using Equation (3).

$$
\% \text { adsorption }=\left[\left(\mathrm{C}_{\mathrm{i}}-\mathrm{C}_{\mathrm{e}}\right) / \mathrm{C}_{\mathrm{i}}\right] \times 100
$$

\section{RESULTS AND DISCUSSION}

The adsorption process between the newly used adsorbent 3 and the phenol adsorbate was thoroughly investigated in order to determine the optimum parameters and adsorption conditions to achieve the maximum removal percentage of the phenol from its standard solution. In addition, the resulted adsorption data was examined different kinetic and isotherm models.

\section{A. Effect of $p H$}

The removal efficiency of the phenol from its standard solution is found to $\mathrm{pH}$-controlled. In the current study, it was found that the phenol adsorption capacity is reached its maximum value at $\mathrm{pH}=5$.

\section{B. Effect of initial concentration}

The initial concentration of the phenol standard solution was investigated against the removal percentage. Three initial concentrations were studied; 1,3 , and $5 \mathrm{ppm}$. The optimum initial concentration to reach the maximum removal percentage was 5 ppm.

\section{Effect of agitation time}

Determining the removal amount of phenol from the standard solution vs. agitating is an essential parameter to determine the adsorption equilibrium and the adsorption rate constant which can be obtained using the kinetic model adopted. The optimum agitating time to reach the maximum removal efficiency was $15 \mathrm{~min}$. The removal percentage of the phenol vs. agitating using compound $\mathbf{3}$ as adsorbent surface is illustrated in Figure 2. 


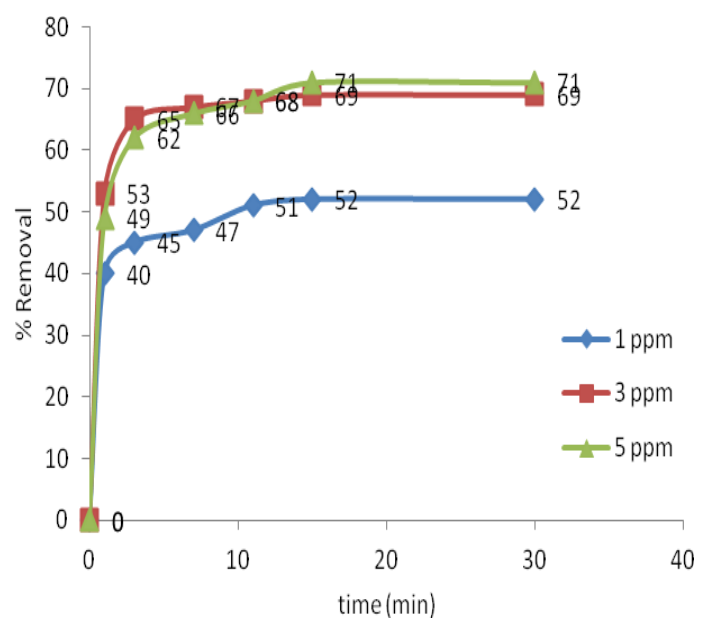

Fig 2. Effect of agitating time on the removal of phenol from its solution at three different initial concentrations.

\section{Effect of temperature}

The temperature effect on the removal percentage of phenol using adsorbent $\mathbf{3}$ was investigated by performing the adsorption experiments at $25,35,40$, and $45{ }^{\circ} \mathrm{C}$. The maximum removal percentage was achieved at $25{ }^{\circ} \mathrm{C}$. Figure 3 shows the relation between the temperature and the removal percentage.

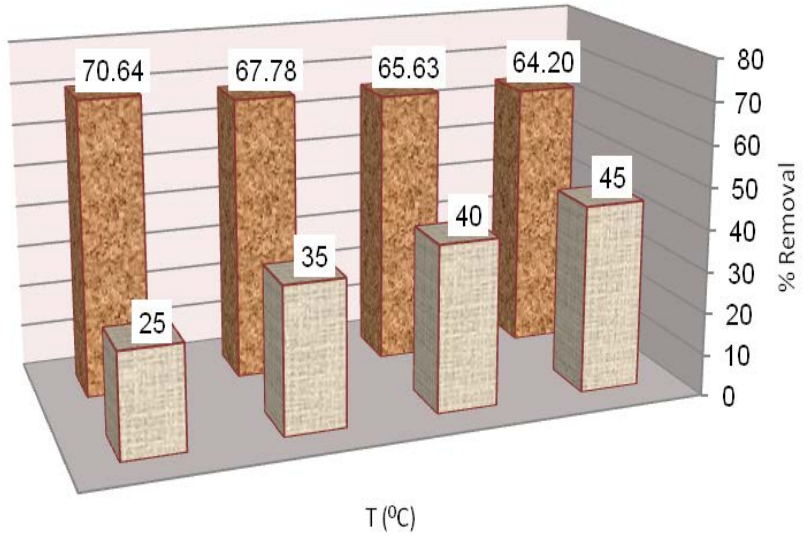

Fig 3. Effect of temperature on the removal percentage of phenol using adsorbent 3.

\section{E. Adsorption kinetics}

Several kinetic models were applied against our adsorption data obtained from the current study. The rate of the adsorption mechanism adopted pseudo- $2^{\text {nd }}$ order of Ho \& McKay model as shown in Figure $4\left(\mathrm{~K}_{2}=0.0871\left(\mathrm{~g} \cdot \mathrm{mg}^{-1} \cdot \mathrm{min}^{-}\right.\right.$ $\left.\left.{ }^{1}\right), q_{e}=35.32 \mathrm{mg} \cdot \mathrm{g}^{-1}, \mathrm{r}^{2}=0.998\right)$ [15].

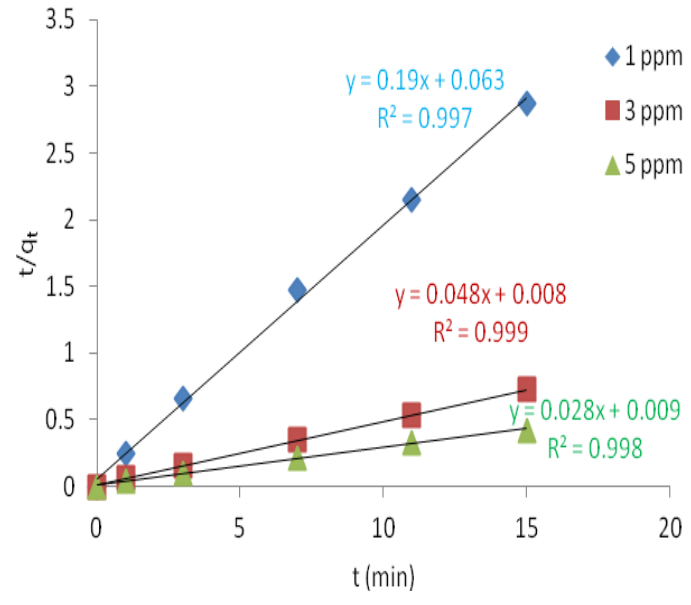

Fig 4. Pseudo-2 ${ }^{\text {nd }}$ order kinetics of phenol adsorption on the adsorbent $\mathbf{3}$ at three different initial concentrations.

\section{F. Adsorption isotherms}

In order to understand the mechanism that describes the adsorption system, we had to study the equilibrium adsorption isotherms very thoroughly. Three models were applied on the current adsorption data; Langmuir isotherm, Freundlich isotherm, and Temkin isotherm [11]. In summary, it's found that the adsorption of phenol onto adsorbent $\mathbf{3}$ is a favorable spontaneous exothermic process.

\section{CONCLUSIONS}

Our results indicated that the newly used adsorbent $\mathbf{3}$ is quite useful in removal the target organic pollutants such as phenol in high removal percentage. The adsorption data adopted Pseudo- ${ }^{\text {nd }}$ order kinetics, and revealed that adsorption of phenol is a favorable spontaneous exothermic process. The research included here is still ongoing, the full paper which will describe thoroughly the complete adsorption process between phenol as organic pollutant and compound $\mathbf{3}$ as organic adsorbent surface will be presented soon somewhere else.

\section{ACKNOWLEDGMENT}

The authors would like to thank Mutah University for providing the research facilities needed to complete this research study. In addition, authors would like to thank The Scientific Research Support Fund (SRSF, Jordan), for financial support through the research grant EWE\2\03\2011.

\section{REFERENCES}

[1] P. D. Rocha, A. S. Franca, L. S. Oliveira, Batch and column studies of phenol adsorption by an activated carbon based on acid treatment of corn cobs, International Journal of Engineering and Technology. 7(6) (2015) 459-464.

[2] V. Srihari, A. Das, Adsorption of phenol from aqueous media by an agro waste (Hemidesmus Indicus) based activated carbon, Applied Ecology and Environmental Research. 7(1) (2009) 12-13.

[3] L. Ma, Q. Chen, J. Zhu, Y. Xi, H. He, R. Zhu, Q. Tao, G. A. Ayoko, Adsorption of phenol and $\mathrm{Cu}(\mathrm{II})$ onto cationic and switterionic surfactant modified montmorillonite in single and binary systems, Chemical Engineering Journal. 283 (2016) 880-888. 
[4] A. Gholizadeh, M. Kermani, M. Gholami, M. Farzadkia, Kinetic and isotherm studies of adsorption and biosorption processes in the removal of phenolic compounds from aqueous solutions: comparative study, Journal of Environmental Health Sciences \& Engineering. 11(29) (2013) 1-10.

[5] A. Ali, K. Saeed, Phenol removal from aqueous mediam using chemically modified banana peels as low-cost adsorbent, Desalination and Water Treatment. (2015) doi: 10.1080/19443994.2015.1041057.

[6] S. F. Alshahateet, A. G. Jiries, S. A. Al-Trawneh, A. S. Eldouhaibi, M. M. Al-Mahadeen, Kinetic, equilibrium and selectivity studies of heavy metal ions (Pb(II), $\mathrm{Co}(\mathrm{II}), \mathrm{Cu}(\mathrm{II}), \mathrm{Mn}(\mathrm{II})$, and $\mathrm{Zn}(\mathrm{II}))$ removal from water using synthesized C-4-methoxyphenylcalix[4]resorcinarene adsorbent, Desalination and Water Treatment. 57 (2016) 4512-4522.

[7] S. F. Alshahateet, Synthesis and supramolecular interactions involved in the crystal structure of (2,4,10,12-tetrabromo-6,7,14,15-tetrahydro-6,14thiacycloocta[1,2-b:5,6- $\left.b^{\prime}\right]$ diquinoline $)_{2} \cdot(1,1,2,2$-tetrachloroethane) inclusion compound, Mol. Cryst. Liq. Cryst. 625 (2016) 186-194.

[8] S. F. Alshahateet, R. Bishop, D. C. Craig, M. L. Scudder, Anomalous inclusion behavior shown by a thia-bridged diquinoline derivative, Crystal Growth \& Design. 10(4) (2010) 1842-1847.

[9] S. F. Alshahateet, A. N. M. M. Rahman, R. Bishop, D. C. Craig, M. L. Scudder, Interlocking molecular grid lattices involving weak assembly forces, CrystEngComm. 4(97) (2002) 585-590.

[10] S. F. Alshahateet, R. Bishop, D. C. Craig, M. L. Scudder, A. T. Ung, Pseudopolymorphic clathrate structures formed by an alicyclic dialcohol inclusion host, Structural Chemistry. 12(3/4) (2001) 251-257.

[11] S. A. Al-Trawneh, Studies on adsorptive removal of some heavy metal ions by Calix[4]resorcine, Jordan Journal of Earth and Environmental Sciences. 7(1) (2015) 1-9.

[12] S. F. Alshahateet, T. T. Ong, R. Bishop, F. Kooli, M. Messali, A dinitrodiphenyldiquinoline host for selective inclusion of polar guests, Crystal Growth \& Design. 6(7) (2006) 1676-1683.

[13] S. F. Alshahateet, New approach for base catalyzed eco-Friendly Friedlander synthesis of racemic 2,10-dinitro-8,16-diphenyl-6,7,14,15tetrahydro-7,15-methanocycloocta[1,2-b:5,6- $\left.b^{\prime}\right]$ diquinoline-Propanoic acid cocrystal: thermal properties, antibacterial activity, and selfassembly, Mol. Cryst. Liq. Cryst. 607 (2015) 169-180.

[14] N. Al-Ghezawi, M. A. Al-Anber, Z. A. Al-Anber, T. El-Hasan and I. Al-Momani, Decontamination and adsorption modelling of aqueous $\mathrm{Pb}^{2+}$ and $\mathrm{Co}^{2+}$ ions using natural inorganic materials: tripoli (NT) and bentonite (NB), Desalination and Water Treatment. 24 (2010) 336-343.

[15] Y. S. Ho and G. Mckay, The Kinetics of Sorption of Divalent Metal Ions onto Sphagnum Moss Peat, Water Research, 34 (2000) 735-742. 